\title{
THE APPLICATION OF MICRO-FOURIER TRANSFORM INFRARED SPECTROSCOPY IN BIOMEDICAL SCIENCES: THE INVESTIGATION OF BIOLOGICAL MINERAL TISSUES AND HISTOPATHOLOGICAL MATERIALS
}

Maja N. Stanković1 , Ružica S. Nikolić1, Dragan M. Đorđević ${ }^{1}$, Nenad S. Krstić1, Miloš G. Đorđević ${ }^{2}$, Jasmina M. Jovanovićs

(ORIGINAL SCIENTIFIC PAPER) UDC 616-00:543.42

1Department of Chemistry, Faculty of Science and Mathematics, University of Niš, Niš,Serbia
2Public Utility Company for Water Supply „Naissus“, Niš, Serbia

${ }^{3}$ High Medical School, Ćuprija, Serbia

Fourier transform infrared (FTIR) spectroscopy is one of the most used experimental techniques for the analysis and characterization of molecular compositions of mineral biological tissues. FTIR microspectroscopy was used to provide spatially resolved information in the micrometer range on the modification of the chemical composition and of the structure of the selected biological mineral tissues and histopathological materials. Structural changes in the bones of Wistar rats due to treating with heavy metals $(\mathrm{Pb}, \mathrm{Cd})$ were investigated. Also, biological minerals formed during pathological states such as kidney stones and crystals excreted at the site of the operational incision after the breast cancer treatment were analyzed. Crystalline calcium oxalates of the studied kidney stones were found in form of monohydrate, and the crystals excreted through the incision scar after the breast cancer operation are mainly formed of lactic acid. The results highlight the benefits of the micro-FTIR analysis providing useful insights into the changes in biological mineral tissues during heavy metal intoxication and other histopathological materials.
Keywords: micro-FTIR, mineral tissues, bone tissue, kidney stone

\section{Introduction}

Fourier transform infrared (FTIR) spectroscopy

Fourier transform infrared (FTIR) spectroscopy is a widely used technique in the case of solid chemical compound identification. It represents a very grateful method because spectral bands in vibrational spectra are molecule specific providing the exact identification of chemical structures, especially of functional groups of organic compounds, bonding types and molecular conformations [1].

In biological and medicine studies, FTIR has become one of the basic instrumental method for characterizing the mineral phase in tissues (physiological, as well as pathological mineral). This technique constitutes an efficient tool to assess both the compositions and the structure of the organic and mineral phase of bones and other mineral tissues and has been widely applied in the detection of diagenetic changes in collagen and carbonate contents. A simultaneous investigation of organic and mineral tissues with visualization of the studied area became possible with the discovery of mercury-cadmium-telluride ( $\mathrm{HgCdTe}$ ) detector leading to the development of a new, non-destructive technique, FTIR microspectroscopy (micro-FTIR). In microFTIR technique, an IR spectrometer is linked to a microscope, and the sample can be either analyzed optically or subjected to IR radiation. The integration of a microscope with the infrared spectrometer in micro-FTIR allows the infrared beam to be focused on microscopic mineral inclusions at specific areas of a larger tissue sample [2]. This technique can thus provide spatially resolved information in the micrometer range with the modification of the chemical composition and of the structure of the studied materials. Micro-FTIR technique enables collecting spectra in transmission, as well as in reflectance mode. Reflectance micro-FTIR spectroscopy yields spectra of somewhat poorer quality than transmission micro-FTIR, but the main advantage of reflectance micro-FTIR is an easier procedure of the sample preparation.

There are a number of scientific papers about applications of FTIR and micro-FTIR in clinical investigations related to malignancy and cancer detection [3-10]. Using these techniques the chemical composition of histopathological and biomaterials without altering morphology can be analyzed [11]. In particular, Marcott et al. [12] investigated hydroxyapatite and protein distributions within bones, while Mendelsohn et al. [13] used micro-FTIR to detect and monitor pathological changes in bones. The possibility of histopathological examination of tissue specimens using micro-FTIR was previously described in dental literature [14]. FTIR spectroscopy has also been widely used for the

Author address: Maja N. Stanković, Department of Chemistry, Faculty of Science and Mathematics, University of Niš, Višegradska 33, P.O. Box 224, 18000 Niš, Serbia

E-mail: majstan@gmail.com

The manuscript received: August, 14, 2015

Paper accepted: September, 30, 2015. 
urinary stones analysis because the routine, easy and rapid measurements give unambiguous information about the stone composition $[15,16]$. To sum up, in medicine, these techniques are used as a tool for the non-invasive analysis of body tissues, or even for in vivo diagnosis of diseases [17].

\section{Mineral tissues}

The mineralized tissues found in vertebrates can be subdivided into those which develop through normal physiologic processes (e.g., bones, teeth, calcified cartilage, etc.), and those that form through pathologic processes (e.g., kidney and salivary stones, atherosclerotic plaques, and other pathologic deposits) [18]. All physiologic deposits are constituted of an analogue of the naturally occurring mineral, hydroxyapatite $\mathrm{Ca}_{10}\left(\mathrm{PO}_{4}\right)_{6}(\mathrm{OH})_{2}$ (hereafter referred as $\mathrm{HA}$ ). Other physiologically mineralized tissues, except teeth enamel which is collagen-free, are deposited upon a collagen matrix.

Distinct spectra of these mineral components make the vibrational spectroscopy (Raman and IR) extensively used to study all of these tissues providing information on the nature of the mineral phases present, quantitative information on the changes in mineral and matrix composition as mineralization occurs, and the nature and amounts of substituent in the mineral $[19,20]$.

Bones produce intense FTIR absorption bands of organic matrix, which is approximately $90 \%$ type I collagen and inorganic (HA) constituents (Figure 1). The primary absorption bands used in the FTIR analysis of the bone are amide I, amide II and amide III (collagen matrix), as well as phosphate, and carbonate (HA) [21], (Table 1). The mineral phase found in bones and teeth is poorly crystalline phase of $\mathrm{HA}$, and contains many lattice vacancies and substitutions. Substitutions may occur in anionic (carbonate may substitute for phosphate and/or hydroxyl group in the lattice) and cationic sites (similar sized metal ions replaced $\mathrm{Ca}^{2+}$ ) depending on the diet and type of bone [22].

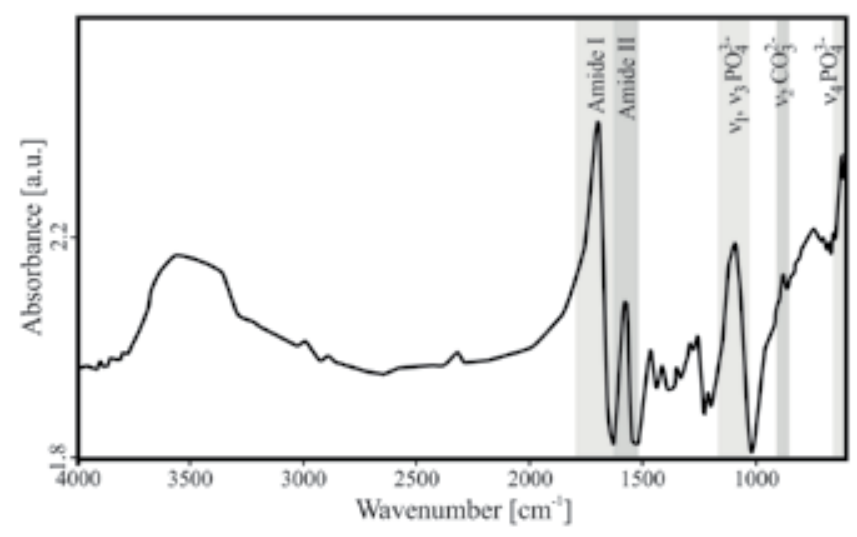

Figure 1. The FTIR spectrum of femur bone (control group of experimental rats) showing regions of: amide I and amide II, $\mathrm{v} 1\left[\mathrm{PO}_{4}^{3-}\right], \mathrm{v} 3\left[\mathrm{PO}_{4}^{3-}\right], \mathrm{v} 4\left[\mathrm{PO}_{4}^{3-}\right]$ and $\mathrm{v} 2\left[\mathrm{CO}_{3}^{2-}\right]$

Table 1. Assignments of absorption bands characteristic for organic matrix and the mineral phase of bone tissue

\begin{tabular}{cccc}
\hline Organic phase & \multicolumn{2}{c}{ Inorganic phase } \\
Assignment & Band & Assignment & Band \\
\hline$v(\mathrm{C}=\mathrm{O}), \mathrm{CONH}$ amide I & $\sim 1655$ & $v_{3}\left[\mathrm{CO}_{3}^{2-}\right]$ & $1410-1450$ \\
$\delta(\mathrm{NH})+v(\mathrm{CN}), \mathrm{CONH}$ amide II & $\sim 1545$ & $v_{1}, v_{3}\left[\mathrm{PO}_{4}^{3-}\right]$ & $900-1200$ \\
$v(\mathrm{CN})+\delta(\mathrm{NH}), \mathrm{CONH}$ amide III & $1200-1400$ & $v_{2}\left[\mathrm{CO}_{3}^{2-}\right]$ & $855-890$ \\
& & $v_{4}\left[\mathrm{PO}_{4}^{3-}\right]$ & $500-650$ \\
\hline
\end{tabular}

Kidney stone formation disease is a common urological disorder with multifactorial etiopathogenesis [23]. The majority of stone formers have disturbances either in the metabolism and excretion of stone constituents or in promoters and inhibitors of crystallization [24]. A study of the chemical composition of kidney stones is important for understanding of their etiology as well. The kidney stones can be classified in seven distinctive types and twenty-one subtypes among monohydrate (whewellite) and dehydrate (weddelite) calcium oxalates, phosphates, uric acid, urates, protein and cystine calculi $[25,26]$. Correctly diagnosed chemical composition of kidney stones is very important for the determination of the appropriate diagnosis and therapeutic regimen [27], the composition of urinary stones also varies from place to place, the investigation of types of the stones and their possible etiological factors is of great importance for the better management of the patients clinically. Thus, the therapy for the stone disease is usually based on the analysis of calculi, permitting a proper management of the disease and the prevention of its recurrence [15]. The recurrence of the stone formation is common; approximately $60 \%$ of the stone formers produce another stone within 10 years after excretion [23].

\section{Experimental}

Micro-Fourier transform infrared (micro-FTIR) spectroscopy

Spectra were collected in reflection mode with a 
Bruker Tensor 27 Hyperion 1000 microscope (Bruker Optik $\mathrm{GmbH}$, Ettlingen, Germany) equipped with a single-point, liquid nitrogen cooled, HgCdTe (MCT) detector, and a $15 \times \mathrm{IR}$ objective. The data were recorded on individual specimens in the region of $4000-600 \mathrm{~cm}^{-1}$ and represent the average of 320 individual scans collected at a spectral resolution of $4 \mathrm{~cm}^{-1}$. Spectra were converted into absorbance using Bruker OPUS software (version 6). Curve fitting analysis was performed using the instrument's software package based on the LevenbergMarquardt algorithm resolving into sums of Lorentzian component bands (and a baseline).

\section{Mineral samples}

Bones. Bone samples (6 female Wistar rats per group, 7 group (control, treated with $\mathrm{Pb}$, treated with $\mathrm{Cd}$, treated with $\mathrm{Pb}$ and lipoic acid, treated with $\mathrm{Pb}$ and glutathione, treated with $\mathrm{Cd}$ and lipoic acid, treated with $\mathrm{Cd}$ and glutathione), 6 weeks of age) have been analyzed in order to recognize eventual changes in the apatite structure as a consequence of an acute intoxication by heavy metals $(\mathrm{Pb}, \mathrm{Cd})$ with and without supplements (lipoic acid, LA and glutathione, GSH). Animals were bred under laboratory conditions and a normal dietary regime in the vivarium of the Faculty of Medicine (University of Niš), in accordance with the rules of the Local Ethic Committee. Animals were euthanized after the final exposure by anesthesia with ketalar (35 mg/kg, intramuscularly) [28]. Freshly dissected bones biopsy cleaned off soft tissue were washed by physiological solution and air-dried on sterile gauze. Micro-FTIR analyses were performed at femur bones of experimental rats without any previous preparation.

Kidney stones The samples of kidney stones were recovered from 12 female patients from Niš (Serbia), age range 35-48 years, from the Hospital of Nephrology, Clinical Center Niš. All stone samples which were excreted via urine stream, were washed by double distilled water, placed on sterile gauze to air-dry, and then stored in glass sterile vials. Micro-FTIR analyses in spectral range of $4000-600 \mathrm{~cm}^{-1}$ were performed on the sample without any previous preparation.

Crystals excreted through the operational incision after mastectomy Prof. Dr Slađana Filipović, renowned oncologist in the Hospital of Oncology (Clinical Center Niš), supplied us with a few pieces of crystals excreted through the operational incision after mastectomy in order to determine their chemical composition. Excreted crystals were collected during the years by J.D., 62 year old female patient from southeastern Serbia.

\section{Results and discussion}

Micro-FTIR and curve-fitting analysis of the bone tissue

The femur bones of experimental animals were analyzed in order to evaluate the eventual changes in a mineral phase as a consequence of an acute intoxication by heavy metals $(\mathrm{Pb}, \mathrm{Cd})$. Experimental animals were exposed to these metals, such as to these metals and supplements, compounds with active - $\mathrm{SH}$ centers (LA and GSH), which form stabile mercaptides with $\mathrm{Pb}$ and $\mathrm{Cd}$ minimizing the toxic effect of the latter. Spectra of bones samples of animals from control group and animals treated with toxic metal solely or with metal + supplements are shown in Figure 2a/b. There are obvious differences for specimens treated with $\mathrm{Pb}$ and $\mathrm{Cd}$ in ${ }_{3} \mathrm{PO}_{4}$ absorption domain $\left(1085 \mathrm{~cm}^{-1}\right)$ [2]. These bands are shifted to higher frequencies. A detailed insight into this region $\left(1400-800 \mathrm{~cm}^{-1}\right)$ is given in Figure $3 \mathrm{a} / \mathrm{b}$. The vertical dashed line is drawn at $1060 \mathrm{~cm}^{-1}$ and is assigned to $\mathrm{P}-\mathrm{O}$ stretching adsorption. Changes in the ${ }_{v 1} \mathrm{PO}_{4}^{3-}$ and ${ }_{3} \mathrm{PO}_{4}^{3-}$ peak position of hydroxyapatite as crystals with intoxicity by heavy metals are evident, i.e., the bands are shifted to higher frequencies for the samples treated only with solutions of $\mathrm{Pb}$ or $\mathrm{Cd}$. With adding supplements as glutathione and lipoic acid, this band is shifted to lower frequencies compared to control group in case of intoxicity with $\mathrm{Cd}$.
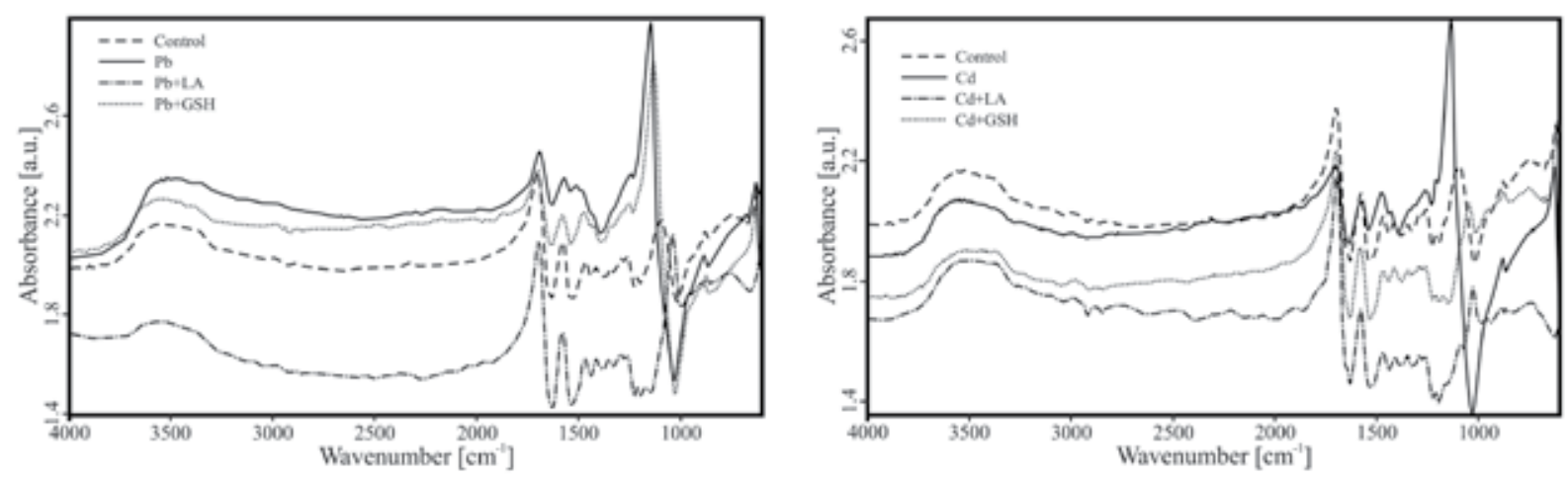

Figure 2. FTIR spectra (4000-600 $\mathrm{cm}^{-1}$ region) of bone samples. 


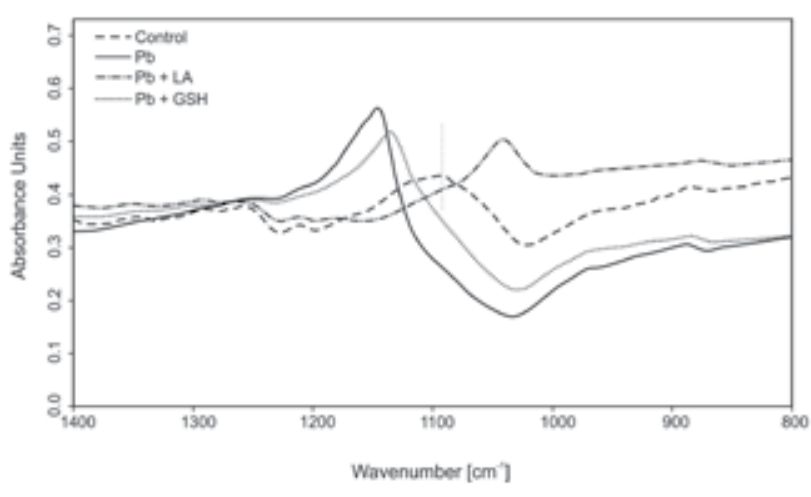

a)

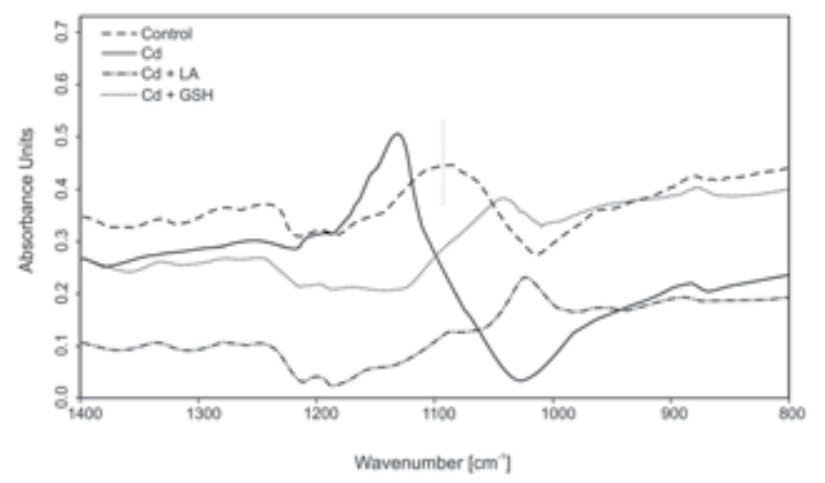

b)

Figure 3. FTIR spectrum of bone samples of control group animals in the $1400-800 \mathrm{~cm}^{-1}$ region of animals treated with $\mathrm{Pb}$ a); of animals treated with $\mathrm{Cd} \mathrm{b}$ )

A region of characteristic absorption for organic matrix and mineral phase is in the frequency range $1700-1200 \mathrm{~cm}^{-1}$. In this region, various functional groups absorb, the absorption frequencies of which are usually overlapped. A curvefitting treatment was carried out to estimate the number and position of the absorption bands (Figure 4). According to this region decomposition, the best fit was obtained by using eight bands at $1244 \mathrm{~cm}^{-1}$ (amide III), $1290 \mathrm{~cm}^{-1}$ (non attributed), $1351 \mathrm{~cm}^{-1}$ (wagging $\left.\mathrm{CH}_{2}\right) 1420 \mathrm{~cm}-1$ (stretching $\mathrm{COO}^{-}$and $\mathrm{O}_{3}^{2-}$ ), $1480 \mathrm{~cm}^{-1}$ (bending $\mathrm{CH}_{2}$ ), $1586 \mathrm{~cm}^{-1}$ (amide II) and $1694 \mathrm{~cm}^{-1}$ (amide I). Bands shapes were considered as Lorentzian with assuming linear baseline. The peak positions, areas and area contributions are tabulated in Table 2. The area contributions were calculated assuming the areas of nine peaks represent $100 \%$ of absorbance in this frequency region.

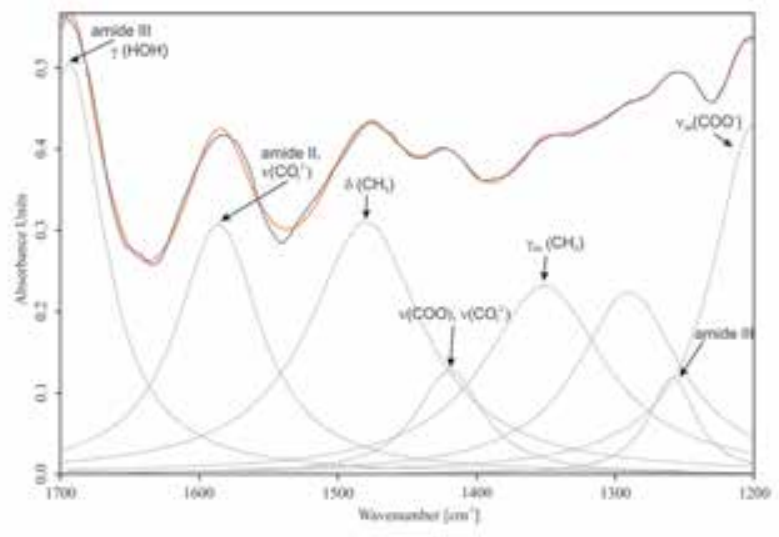

Figure 4. The curve fitting analysis of absorbance bands in the frequency range $1700-1200 \mathrm{~cm}^{-1}$
Table 2. The peak position and area of individual component bands in $1700-1200 \mathrm{~cm}^{-1}$ region for FTIR spectrum of bone samples of control group animals

\begin{tabular}{crccc}
\hline Position & Height & Width & \multicolumn{1}{c}{ Area } & \% Area \\
\hline 1199 & 0.430 & 71.6 & 48.420 & 17.74 \\
1244 & 0.058 & 24.8 & 2.262 & 3.67 \\
1290 & 0.224 & 90.9 & 32.001 & 11.72 \\
1351 & 0.231 & 106.6 & 38.755 & 14.20 \\
1419 & 0.127 & 58.1 & 11.643 & 4.26 \\
1480 & 0.310 & 99.8 & 48.570 & 17.79 \\
1586 & 0.307 & 73.8 & 35.550 & 13.02 \\
1694 & 0.506 & 60.5 & 48.052 & 17.60 \\
\hline
\end{tabular}

Micro-FTIR analysis of kidney stone

As an example of the common application of the microFTIR technique in the investigation of histopatological materials in Figure 5a FTIR spectra of a kidney stone for the identification of its chemical composition are exhibited, as well as microphotographs of the material surface (Figure $5 b)$. In FTIR spectra of kidney stones various bands according different chemical composition occur: the strong bands around $778,1316,1640 \mathrm{~cm}^{-1}$ corresponding to calcium oxalate; $1638 \mathrm{~cm}^{-1}$ corresponding to pure uric acid; 2363, $1459 \mathrm{~cm}-1$ characteristic for magnesium ammonium phosphate; bands around 740, 779, 1314, 1315, 1637 , and $1636 \mathrm{~cm}^{-1}$ corresponding to the mixture of uric acid and calcium oxalate [15]. FTIR analyses of the investigated kidney stones show that the samples represent mainly homogenous material, and according to characteristic absorption bands around 683, 779, 883, 1315, 1380 , and $1640 \mathrm{~cm}^{-1}$ it can be determined that the sample is of mostly calcium oxalate monohydrate composition (whewellite). A calcium oxalate monohydrate stone mainly develops due to hyperoxaluria - a metabolic disorder causing the stone formation. Oxalate represents the end product of several metabolic pathways. 
These results are in accordance with the statistical data that in most countries over the world calcium oxalate monohydrate accounts for the more common and more abundant component of stones [29].

Micro-FTIR analysis of breast excreted crystals

The FTIR analysis of a unique solid material excreted through the operational cut after the breast cancer operation was important in order to determine a chemical composition and, consequently the ways of forming this extraordinary material. The analysis shows that the excreted material is very homogenous due to the absence of significant differences in FTIR spectra of different surface locations. Characteristic absorption bands around 1127 and $1730 \mathrm{~cm}^{-1}$, as well as the intense hydroxyl band around $3200 \mathrm{~cm}^{-1}$ and aliphatic absorption below $3000 \mathrm{~cm}^{-1}$ implies that the investigated material is mainly composed of lactic acid (Figure 6a/b).

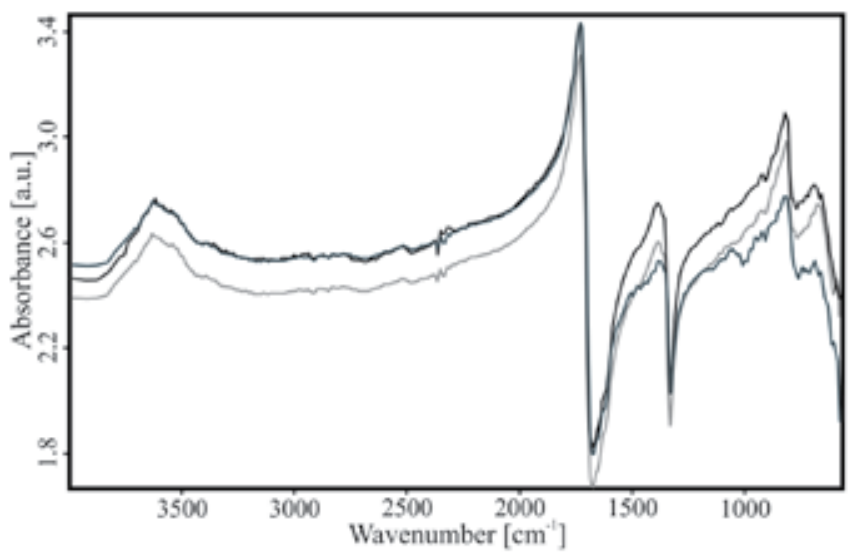

a)

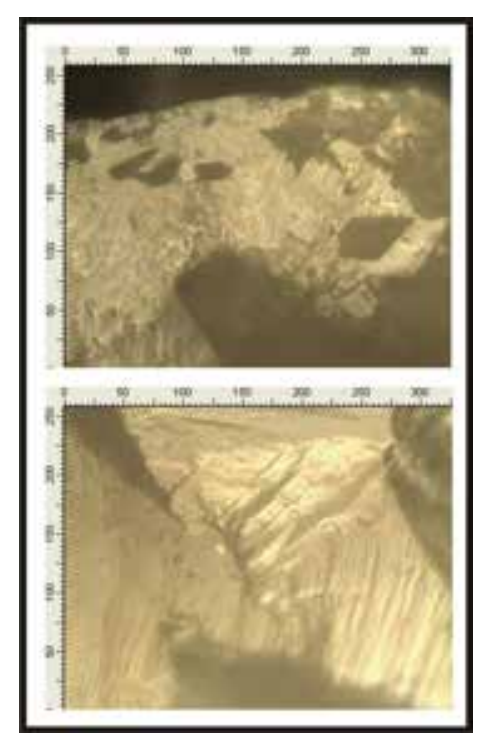

b)

Figure 5. a) FTIR spectrum of the kidney stone; b) micro-photographs of the investigated sample surfaces.

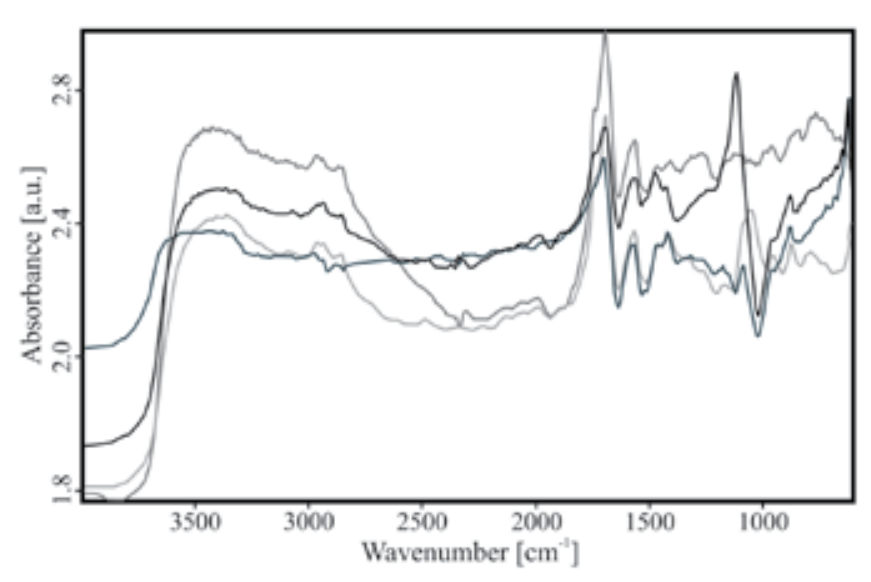

a)

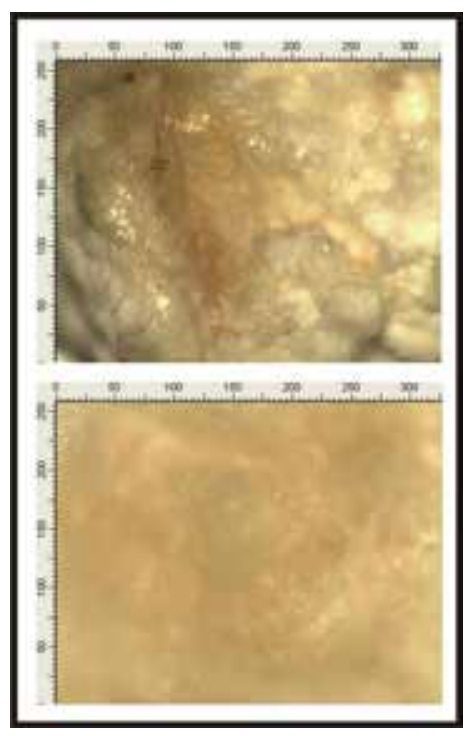

b)

Figure 6. a) FTIR spectrum of breast excreted crystals; b) micro-photographs of the investigated sample surfaces.

\section{Conclusion}

The reflectance micro-FTIR technique allows rapid, reliable identifications of even a small amount of mineral tissues and histopathological materials, without complicated sample preparation with the destruction of the investigated specimens, against traditional transmittance FTIR techniques based on $\mathrm{KBr}$ pellets preparation. Also, the integrated microscope enables simultaneous visualization of the sample surface and distinct spatial IR characterization. This technique proves to be useful in monitoring the type and degree of structural changes of mineral tissues in conditions of acute or chronically intoxicity with heavy metals.

Just a small part of the information which can be obtained by using micro-FTIR as a tool that provides simultaneous spatially resolved information in the micrometer range on the modification of the chemical composition and of the structure of studied materials is presented here. 


\section{Acknowledgments}

Authors kindly thank Prof. Dr Slađana Filipović for providing samples of unique histopathological material. This paper was founded by the Ministry of Education and Science of the Republic of Serbia under projects TR31060 and TR34008.

\section{References}

[1] Z. Movasaghy, S. Rehman, I. Rehman, Fourier transform infrared (FTIR) spectroscopy of biological tissues, Applied Spectroscopy Review, 43 (2008) 134-179.

[2] J. D. Featherstone, S. Pearson, R. Z. Le Geros, An infrared method for quantification of carbonate in carbonate apatites, Caries Research, 18(1) (1984) 63-66.

[3] R. R. Alfano, G. C. Tang, A. Pradhan, V. Lam, D. S. J. Choy, E. Opher, Optical spectroscopic diagnosis of cancer and normal breast tissues, Journal of Optical Society of America B, 6(5) (1987) 1015-1023.

[4] Y. Yang, J. Sule-Suso, G. D. Sockalingum, G. Kegelaer, M. Manfait, A. J. El Haj, Study of tumor cell invasion by Fourier transform infrared micro-spectroscopy, Biopolymers, 78 (2005) 311-317.

[5] S. Mordechai, A. O. Salman, S. Argov, B. Cohen, V. Erukhimovitch, J. Goldstein, O. Chaims, Z. Hammody, Fourier transform infrared spectroscopy of human cancerous and normal intestine, Proceedings of the SPIE, 3918 (2000) 66-77.

[6] P. G. L. Andrus, R. D. Strickland, Cancer grading by Fourier transform infrared spectroscopy, Biospectroscopy, 4 (1998) 37-46.

[7] P. G. L. Andrus, Cancer monitoring by FTIR spectroscopy, Technology in Cancer Research and Treatment, 5(2) (2006) 157-167.

[8] P. K. Sahu, S. Mordechai, Fourier transform infrared spectroscopy in cancer detection, Future Oncology, 1 (2005) 635-647.

[9] M. J. Walsh, M. J. German, M. Singh, H. M. Pollock, A. Hammiche, M. Kyrgiou, H. F. Stringfellow, E. Paraskevaidis, P. L. Martin-Hirsch, F. L. Martin, IR microspectroscopy: potential applications in cervical cancer screening, Cancer Letters, 246 (2007) 1-11.

[10] B. Bird, M. Miljković, S. Remiszewski, A. Akalin, M. Kon, M. Diem, Infrared spectral histopathology (SHP): a novel diagnostic tool for the accurate classification of lung cancer, Laboratory investigation, 92 (2012) 1358-1373.

[11] E. P. Paschalis, K. Verdelis, S. B. Doty, A. L. Boskey, R. Mildensohn, M. Yamauchi, Spectroscopic characterization of collagen cross-links in bones, Journal of Bone and Mineral Research, 16(10) (2001) 1821-1828.

[12] C. Marcott, R .C. Reeder, E. P. Paschalis, A. L. Boskey, R. Mendelsohn, Infrared Microspectroscopic Imaging of Biomineralized Tissues using a Mercury-CadmiumTelluride Focal-Plane Array Detector, Phosphorus, Sulphur and Silicon, 146 (1999) 417-420.

[13] R. Mendelsohn, E. P. Paschalis, P. J. Sherman, A. L. Boskey, IR Microscopic Imaging of Pathological States and Fracture Healing of Bone, Applied Spectroscopy, 54(8) (2000) 1183-1191.

[14] W. Hedzelek, R. Wachowiak, A. Marcinkowska, L. Bomka, Infrared spectroscopic identification of chosen dental materials and natural teeth, Acta Physica Polonica A, 114
(2008) 471-484.

[15] C. Paluszkiewicz, S. Jand, M. Galka, Analysis of renal stones by FTIR spectroscopy, Microchimica Acta, 94(1-6) (1988) 45-48.

[16] N. A. Channa, A. B. Ghangro, A. M. Soomro, L. Noorani, Analysis of kidney stones by FTIR spectroscopy, JLUMHS, (2007) 66-73.

[17] K. S. Kalasinsky, V. F. Kalasinsky, Infrared and Raman microspectroscopy of foreign materials in tissue specimens, Spectrochimica Acta Part A: Molecular and Biomolecular Spectroscopy, 61 (2005) 1707-1713.

[18] A. L. Boskey, R. Mendelsohn, Infrared spectroscopic characterization of mineralized tissues, Vibrational Spectroscopy, 38(1-2) (2005) 107-114.

[19] L. Jr. Silveira, S. Sathaiah, R. A. Zangaro, M. T. Pacheco, M. C. Chavantes, C. A. Pasqualucci, Correlation between near-infrared Raman spectroscopy and the histopathological analysis of atherosclerosis in human coronary arteries, Lasers in Surgery and Medicine, 30 (2002) 290-297.

[20] C. Li, D. Ebenstein, C. Xu, J. Chapman, D. Saloner, J. Rapp, L. Pruitt, Biochemical characterization of atherosclerotic plaque constituents using FTIR spectroscopy and histology, Journal of Biomedical Materials Research Part A, 64(2) (2003) 197-206.

[21] S. Gourion-Arsiquaud, P. A. West, A. L. Boskey, Fourier Transform-Infrared Microspectroscopy and microscopic imaging, Methods in Molecular Biology, 455 (2008) 293303.

[22] J. Anderson, J. Dellomo, A. Sommer, A. Evan, S. Bledose, A concerted protocol for the analysis of mineral deposits in biopsied tissue using infrared microanalysis, Urological Research, 33 (2005) 213-219.

[23] S. R. Khan, in Urinary tract stone disease, N. P. Rao, G. M. Preminger, J. P. Kavanagh, Eds., Springer, London, 2011, p. 61.

[24] M. Daudon, C. A. Bader, P. Jungers, Urinary calculi: review of classification methods and correlations with etiology, Scanning Microscopy, 7 (1993) 1081-1106.

[25] M. Daudon, P. Jungers, in Urolithiasis: basic science and clinical practice, J. J. Talati, H. G. Tiselius, D. M. Albala, Z. Ye, Eds., Springer, London, 2012, p. 113.

[26] A. A. Siddiqui, T. Sultana, N. P. Bucholz, M. A. Waqar, J. Talati, Proteins in renal stones and urine of stone formers, Urological Research, 26 (1998) 383-388.

[27] F. Kesner, I. Dominak, Kidney stone analysis by Nicolet FTIR spectrometer, http://www.ftir.cz/Kidclan2.pdf

[28] R. S. Nikolić, J. M. Jovanović, G. M. Kocić, T. P. Cvetković, S. R. Stojanović, T. D. Anđelković, N. S. Krstić, Monitoring the effects of exposure to lead and cadmium in working and living environment through standard biochemical blood parameters and liver endonucleases activity, Chemical Industry, 65(4) (2011) 403-409.

[29] J. Cloutier, L. Villa, O. Traxer, M. Daudon, Kidney stone analysis: "Give me your stone, I will tell you who you are!", World Journal of Urology, 33 (2015) 157-169. 
Izvod

\section{PRIMENA MIKRO-FOURIER TRANSFORMACIONE INFRACRVENE SPEKTROSKOPIJE U BIOMEDICINSKIM NAUKAMA; ISPITIVANJE BIOLOŠKIH MINERALNIH TKIVA I HISTOPATOLOŠKIH MATERIJALA}

Maja N. Stanković ${ }^{1}$, Ružica S. Nikolić ${ }^{1}$, Dragan M. Đorđević ${ }^{1}$, Nenad S. Krstić1, Miloš G. Đorđević2 ${ }^{2}$ Jasmina M. Jovanović ${ }^{3}$

(ORIGINALNI NAUČNI RAD)

UDK 616-00:543.42

1 Prirodno-matematički fakultet, Katedra za hemiju, Univerzitet u Nišu, Niš, Srbija

2 JKP za vodovod i kanalizaciju „Naisus“, Niš, Srbija

3 Visoka medicinska čkola strukovnih studija, Ćuprija, Srbija

Fourier-ova transformaciona infracrvena(FTIR) spektroskopijajejedna od najčešće korišćenih eksperimentalnih tehnika prilikom analize i karakterizacije molekulskog sastava mineralnih tkiva. Modernija tehnika, FTIR mikrospektroskopija, danas se češće koristi za dobijanje informacija o promenama hemijskog sastava i strukture kako mineralnih tkiva tako i histopatološkog materijala na mikrometarskom uzorku. U ovom radu, FTIR-mikroskopija je korišćena za praćenje strukturnih promena mineralnog tkiva pacova tretiranih teškim metalima $(\mathrm{Pb}, \mathrm{Cd})$. Takođe, ispitivana su i patološka stanja, kao što su formiranje bubrežnog kamena i lučenje kristala na mestu operativnog reza nakon mastektomije kod pacijentkinje koja se lečila od kancera dojke. Utvrđeno je da su bubrežni kamenčići pripadali klasi kalcijumoksalata monohidrata, dok je materijal izlužen nakon mastektomije uglavnom izgrađen od mlečne kiseline. Ispitivanje ukazuje na prednosti korišćenja mikroFTIR analize u medicinskoj dijagnostici mineralnih tkiva i drugog histopatološkog materijala.
Ključne reči: mikro-FTIR, mineralna tkiva, koštano tkivo, bubrežni kamen 